\title{
PEMAKNAAN MEME STIKER WHATSAPP SEBAGAI BENTUK EKSPRESI MILENIAL
}

\author{
Aryo Bimo \\ Magister Ilmu Komunikasi STIKOM InterStudi, Jakarta \\ obeems.work@gmail.com \\ Martani Huseini \\ Departemen Ilmu Administrasi, Universitas Indonesia, \\ martani0703@yahoo.com \\ Kinkin Yuliaty Subarsa \\ Departemen Ilmu Komunikasi, Fakultas Ilmu Komunikasi, \\ Universitas Negeri Jakarta \\ kinkinsubarsa@unj.ac.id
}

\section{Rosita Anggraini}

Program Pascasarjana, Magister Ilmu Komunikasi STIKOM InterStudi, Jakarta rosita.tagor@gmail.com

\begin{abstract}
This digital era has made human interaction, which was done face-to-face, switch to using conversation applications or social media. A meme is a popular digital object that people can save, share and create / modify. One of these memes is a WhatsApp sticker. WhatsaApp is a conversation application that is often used in the digital age. Millennials who were born in the digital era have made WhatsApp a medium to interact with each other. Interactions that were in the form of symbols in the form of language, gestures, expressions were replaced with WhatsApp sticker memes. The phenomenon that occurs on WhatsApp is the use of stickers. These stickers can be classified in the meme category because they are digital objects in the form of photos or illustrations complete with text and can be shared with other people, and can be changed or modified by each user. This research is based on the author's assumption that millennials communicate through meme stickers as a form of self-expression within the framework of symbolic interactions. The purpose of this research is to prove this assumption. This research uses a qualitative method and is seen from the theory of symbolic interaction by interviewing several millennials to see how these millennials use WhatsApp stickers based on the symbolic meaning of the stickers related to themselves. Symbolic interaction is a process of interpreting actions because symbolic meanings can be formed differently for each person. The goal to be achieved is to see whether the use of WhatsApp stickers is interpreted as self-expression that appears as a result of actions to respond to what happens in interactions with other people. The results showed that the exchange of symbols that occurred with WhatsApp stickers was interpreted and used to respond to an interaction that occurred.
\end{abstract}

KEYWORDS: STICKERS, WHATSAPP, SYMBOLIC INTERACTION, EXPRESSION 


\section{PENDAHULUAN}

Sebagai makhluk sosial dengan sendirinya manusia akan berinteraksi antara sesama manusia, baik itu antara individu dengan invidu atau individu dengan seklompok invidu lainnya. Pada era digital sekarang ini proses interaksi antar manusia mengalami perubahan. Teknologi digital memungkinkan manusia berinteraksi secara tidak langsung. Dengan adanya teknologi informatika memungkinkan manusia berinteraksi melalui perantaraan medium baru seperti yang kita kenal dengan media sosial seperti Instagram, Facebook, Twitter dan juga aplikasi percakapan seperti LINE, TelegramWhatsApp dan lainnya.

Interaksi adalah satu hubungan yang terjadi antar indvidu dengan individu lain sedemikian rupa sehingga invidu yang bersangkutan saling mempengaruhi satu sama lain. Interaksi merupakan proses saling bertukar informasi, bertukar simbol melalui bahasa (verbal). Interaksi dalam bentuk pertukaran simbol antar manusia diwakili dengan bahasa/verbal, gestur tubuh atau ekspresi tubuh sementara di era digital komunkasi selain secara tatap muka dapat dilakukan melalu media sosial dan aplikasi percakapan atau aplikasi penyampai pesan. Dengan media sosial interaksi tersebut diwakilkan dengan visual yang berupa foto, audio dan bahkan video. Apalagi di era pandemi seperti sekarang ini media digital tersebut lebih diutamakan dan digunakan dengan lebih intens karena tatap muka secara fisik sangat dibatasi, bahkan tidak diperkenankan orang untuk bertemu langsung. Sehingga sekarang banyak akhirnya pertemuan-pertemuan dilakukan via daring (online) dengan menggunakan aplikasi teleconference seperti Zoom, Google Meet yang bisa dilakukan melalui perangkat keras seperti laptop dan juga di telepon pintar.

\section{TINJAUAN PUSTAKA}

Ekspresi berupa simbol seperti bahasa (verbal), ekspresi wajah dan gestur tubuh di era digital ini diwakilkan degan berbagai macam objek digital seperti emoticon, penggunaan huruf besar (Kapital), huruf tebal (bold). Seperti dalam jurnal Rifqi Fauzi (2017) bahwa ada perubahan pola dan cara berkomunkasi dari konvensional ke era digital dan WhatsApp menjadi salah satu aplikasi percakapan yang sangat popular di era digital sekarang. Interaksi yang terjadi di dunia digital berupa medium teks. Nasrullah (Fauzi, 2017) dalam bukunya Teori dan Riset Media Siber (Cybermedia) mengatakan bahwa ada dua terminologi yang digunakan untuk pendekatan pengunaan Bahasa di media digital. (1) Netspeak bentuk pembicaraan yang berupa tulisan. Bentuk pembicaraan yang mewakili penulisan misalnya kata "hahahaha" atau "wkwkwkwk". (2) Netlingo dimana bahasa teks baku seakan-akan mewakili ekspresi ketika berbicara. Ekspresi diwakili dengan simbol emoticon, untuk mengekspresikan senyum diwakili dengan simbol "(:)" sedangkan untuk mewakili ekspresi sedih atau kecewa dengan simbol ":;".

Kemudian dengan munculnya meme internet memperkaya simbol ekspresi di era digital sekarang ini. Menurut Limor Shifman (2014, hal. 41) dalam bukunya yang berjudul Meme: in Digital Culture mendefinisikan ulang meme menjad isebagai berikut:

a) Sekumpulan item digital yang memiliki ciri khas yang sama tentang konten (isi), bentuk, dan atau sikap

b) Diciptakan dengan sadar akan keberadaan satu sama lain, dan 
c) Diedarkan, diduplikasi, dan / atau dimodifikasi sedemikan rupa melalui Internet oleh orang lain.

Pada perkembanganya meme yang awalnya hanya berupa gambar diam dipadukan dengan teks, sekarang ada yang bergerak seperti animasi GIF dan bahkan berbentuk audio visual atau video berdurasi pendek. Ada yang berupa stiker seperti yang dapat ditemukan di aplikasi percakapan WhatsApp. Seperti yang dikatakan oleh Limor di atas dapat disimpulkan bahwa stiker WhatsApp ini termasuk meme. Karena merupakan objek digital yang dapat dibuat, dimodifikasi disebarkan.

Stiker tersebut merupakan salah satu fitur WhatsApp. Stiker WhatsApp ini ada yang gratis bisa diunduh langsung ada pula yang berbayar. Stiker WhatsApp ini sangat beragam dengan format umunya terdiri atas ilustrasi dan teks. Stiker tersebut setelah diunduh akan langsung otomatis tersimpan dalam gallery, sehingga kapan dibutuhkan dapat digunakan langsung. Pada perkembangannya stiker ini pun mengalami perkembangan dan semakin beragam temanya, bahkan ada juga yang dalam format bergerak atau animasi. Visualnya pun beragam, ada yanghanya berupa teks saja, ada yang hanya berupa gambar saja tanpa teks, ada yang gabungan gambar dengan teks dan seterusnya.

Stiker WhatsApp ini juga dapat dibuat sendiri oleh pengguna WhatsApp (AlMaroof et al., 2021), sudah banyak aplikasi pembuat stiker yang dapat diunduh. Jadi pengguna WhatsApp pun dapat membuat stikernya sendiri yang sesuai dengan kebutuhan pribadinya. Faktor ini yang membedakannya dari aplikasi lain. Mekanisme pembuatan stiker ini merupakan suatu pengalaman baru yang juga menciptakan hubungan emosional dengan si pembuat sehingga muncul rasa memiliki dan kepemilikan terhadap stiker tersebut. Pengguna jadi termotivasi sehingga mempengaruhi frekuensi penggunaan stiker dan mejadi lebih tersebar luas. Jadi penggunaan stiker ini tidak hanya dari sisi emosional tapi juga dari sisi fungsional dan strategis.

Dari hasil pengamatan dan pengalaman penulis sendiri dalam menggunakan stiker WhatsApp, stiker tersebut dapat dibedakan atau dibagi kedalam beberapa versi seperti yang bisa dilihat pada tabel di bawah ini:

Tabel 1. Kategori atau Versi stiker WhatsApp

\begin{tabular}{|c|c|c|}
\hline Stiker WA & Versi/Kategori & Penjelasan \\
\hline $\begin{array}{c}\text { Stiker berupa } \\
\text { teks saja tanpa } \\
\text { visual }\end{array}$ & $\begin{array}{c}\text { Biasanya kata-kata bertemakan } \\
\text { motivasi, pujian, sinis atau sarkasme } \\
\text { dan lain-lain }\end{array}$ \\
\hline $\begin{array}{c}\text { Seri Bang } \\
\text { Rhoma }\end{array}$ & $\begin{array}{c}\text { Menggunakan foto dari artis penyanyi } \\
\text { dangdut terkenal, Rhoma Irama }\end{array}$ \\
\hline & Seri "plesetan" & $\begin{array}{c}\text { Kata-kata yang merupakan "plesetan" } \\
\text { dari visual/gambar stikernya }\end{array}$ \\
\hline
\end{tabular}


Dapat dilihat pada tabel di atas bahwa stiker WhatsApp ini terdiri dari banyak kategori yang penulis cantumkan hanya beberapa dari sekian banyak stiker WhatsApp yang beredar.

Stiker tersebut ada yang bisa dibuat sendiri dengan aplikasi pembuat stiker meme. Tinggal kita pilih foto yang akan kita jadikan meme lalu dimodifikasi dengan aplikasi tersebut setelah itu bisa disimpan di gallery stiker WhatsApp.

Fenomena Stiker WhatsApp ini membuat orang semakin lebih sering menggunakan aplikasi WhatsApp. Dengan stiker mereka bisa saling bertukar simbol, bisa saling memberikan komentar yang diwakilkan dengan stiker tersebut, bisa berbalas stiker atau yang kerap disebut dengan istilah "Sticker War" atau perang stiker. Bahkan ada juga karena stiker ini menyebabkan kehebohan seperti yang diberitakan di media suara.com ada seorang anak yang salah memberikan stiker ketika sedang melakukan percakapan via WhatsApp terhadap ibunya. Kesalahan kirim stiker tersebut sempat memperkeruh hubungan antara si anak dengan orang tuanya. Jadi berhati-hatilah saat berinteraksi via WhatsApp dengan menggunakan stiker (Pratnyawan, 2019). Jika salah kirim stiker pada seseorang bisa mengakibatkan kesalahpahaman. Fenomena yang lain juga adalah maraknya kemunculan grup-grup WhatsApp. Grup ini dibuat berdasarkan kesamaan lingkungan misalnya grup keluarga, grup teman sekantor, grup teman SMA, grup pengajian dan lain sebagainya.

Adapula yang mendeskripsikan karakter orang dari cara mengunakan Whatsapp seperti yang pernah dimuat di media hipwee.com. Hipwee (Revitasari, 2015) mengatakan ada 31 jenis tipe orang yang akan dapat kita jumpai dalam grup-grup WhatsApp. Beberapa diantaranya ada yang memiliki karakteristik seperti motivator ala Mario Teguh. Ada yang suka copy paste tulisan orang lain biasanya terjadi pada saat memberikan ucapan baik itu ucapan selamat atas sesuatu hal yang gembira atau kabar duka. Ada juga istilah "Silent Reader" yaitu salah satu anggota grup WhatsApp yang tidak pernah muncul dalam percakapan di grup tersebut.

Jurnal sebelumnya yang membahas seputar stiker dan interkasi penulis menemukan beberapa jurnal yang masih relevan walaupun bukan tentang stiker Whatsapp adalah jurnal Gitari (Jessica \& Franzia, 2017) yang meneliti tentang stiker LINE Cony versi edisi khusus. Hasil penelitian mengatakan bahwa walaupun sebagian besar pengguna LINE mengatakan tidak mengetahui arti dan tujuan dari stiker LINE tersebut tapi mereka bisa mengartikannya sesuai dengan perasaan dan apa yang ingin disampaikan si pengguna dengan melihat visual stiker LINE tersebut.

Jurnal yang lain juga meneliti tentang stiker LINE adalah jurnal Indriani (Indriani, Sri Seti, Prasanti, 2019) sebagai budaya tutur digital dalam personal branding yang mengatakan bahwa para pengguna stiker LINE membeli danmengunduh stiker yang dianggap bisa mepresentasikan diri dan perasaan mereka. Selain itu stiker juga bisa mewakili pernyataan melalui Bahasa yang non verbal atau visual.

\section{Teori Interaksi Sosial}

Teori interaksionisme simbolis (Arif: 2015) menurut Riyadi Soeprapto dalam bukunya Interaksionisme Simbolik tahun 2002 memiliki tiga hakikat pemikiran sebagai berikut: 
- Respon manusia terhadap benda atas dasar "arti" yang dimiliki benda tersebut.

- Sumber makna dari benda-benda tersebut yang muncul dari hubungan sosial yang dimiliki seseorang.

- Pemaknaan tersebut dilakukan dan dimodifikasi melalui proses interpretasi manusia atas berbagai benda yang dijumpainya.

Teori Interaksi simbolik yang digadang oleh Blumer (Griffin, 2012, hal. 55-58) terdiri atas premis sebagai berikut:

1. Manusia akan merespon orang atau benda atas dasar pemaknaan terhadap orang atau benda tersebut.

2. Makna yang muncul dari interaksi sosial antara seseorang dengan orang lain.

3. Interpretasi individu terhadap simbol dimodifikasi oleh proses pemikirannya sendiri saat proses interaksi sosial berlangsung.

Seperti yang dikatakan Blummer (Ahmadi, 2016) interaksi manusia akan dijembatani oleh penggunaan simbol, penafsiran dan penemuan makna atas tindakan orang lain. Sehingga dalam konteks tersebut manusia sebagai actor (subjek) akan memilih, memeriksa, berpikir, mengelompokan dan mengubah rupa makna sesuai situasi dan kecenderungan tindakannya.

Interaksi simbolik timbul karena adanya ide dasar yang lalu membentuk sebuah arti yang berasal dari pikiran manusia (mind) tentang dirinya (self) dan hubungannya pada interaksi sosial dan bagaimana arti tersebut bisa didefinisikan di tengah masyarakat (society) di mana individu itu berada. (Siregar, 2011).

Manusia akan merespon atau bertindak terhadap sesuatu (simbol) atas dasar pemaknaan, di mana makna tersebut muncul dari proses interaksi satu individu dengan yang lainnya. Atau dengan kata lain interaksionisme simbolik melihat makna akibat penciptaan yang terbentuk melalui aktivitas yang terinterpretasikan saat mereka melakukan interaksi (Putro, 2017).

Interaksi dalam era digital ini berlangsung di media sosial dan aplikasi percakapan. Interaksi yang terjadi dalam bentuk simbol yang diwakilkan dengan meme yang dalam aplikasi percakapan WhatsApp dalam bentuk stiker. Konsep pemikiran (mind) dalam interaksi simbolik ini bagaimana individu tersebut bertindak atau memberikan respon berdasarkan pemaknaan yang diberikan terhadap stiker yang mereka dapatkan.

Dari beberapa fenomena dan penelitian dari beberapa jurnal yang penulis sudah jabarkan di atas, penulis melihat bahwa pertukaran pesan, simbol, ekspresi dan gestur juga terjadi dalam interaksi digital tidak berubah hanya medium dan cara berinteraksi yang berubah. Ekspresi tersebut diwakili dengan oleh meme dalam bentuk stiker WhatsApp. Adanya keterlibatan secara emosional dan peran society yang membuat mereka menggunakan stiker tersebut untuk memaknai suatu interaksi yang terjadi dalam percakapan di WhatsApp, baik personal maupun di grup-grup WhatsApp. Penulis memiliki asumsi bahwa stiker WhatsApp yang digunakan (dikoleksi dan dibagikan) akan memiliki kesesuaian dengan pribadi yang individu tersebut miliki. Sehingga tujuan dari penelitian ini adalah untuk melihat apakah penggunaan stiker WhatsApp ini dimaknai 
sebagai ekspresi diri yang muncul sebagai akibat tindakan untuk merespon apa yang terjadi dalam interaksi dengan orang lain.

\section{METODE PENELITIAN}

Metode yang digunakan adalah metode kualitatif. Penelitian kualitatif adalah penelitian yang meneliti kondisi objek apa adanya, teknik pengumpulan data dilakukan dengan mengadakan wawancara dengan para nara sumber yang sesuai dengan kriteria, yaitu milenial, dan juga menggunakan data yang diambil dari data literatur. Data yang dihasilkan bersifat deskriptif, analisis data dilakukan secara induktif, dan penelitian ini lebih menitikberatkan pada pemaknaan daripada generalisasi (Sedarmayanti dan Hidayat, 2011: 33).

Menurut Pew Research Center generasi milenial atau yang juga dikenal dengan nama generasi "Y" merupakan generasi yang memiliki tahun kelahiran 1981 sampai dengan 1996 (Dimock, 2019). Seperti yang sudah ditulis di atas berdasarkan riset yang dilakukan oleh Alvara Research Center bahwa milenial adalah pemakai terbanyak internet khususnya dari telepon pintar. Jadi penulis akan mewawancarai beberapa informan yang memiliki krtieria sebagai berikut:

- Laki-laki dan perempuan

- Tahun kelahiran 1980-1996 (milenial)

- Pendidikan S1

- Pengguna telepon pintar (smart phone)

- Pengguna WhatsApp dan memiliki stiker

\section{PEMBAHASAN}

Adapun yang informan yang diwawancara adalah:

Tabel 2. Informan

\begin{tabular}{|r|l|c|c|}
\hline \multicolumn{1}{|r|}{ No } & Nama & $\begin{array}{c}\text { Jenis } \\
\text { Kelamin }\end{array}$ & Umur \\
\hline 1. & Pandu & Laki-laki & 33 tahun \\
\hline 2. & Celine & Perempuan & 24 tahun \\
\hline 3. & Moksa & Laki-laki & 38 tahun \\
\hline 4. & Iyus & Laki-laki & 31 tahun \\
\hline
\end{tabular}

Pengumpulan data dalam penelitian ini menggunakan wawancara mendalam dan observasi. Mereka semua adalah pengguna WhatsApp. WhatsApp digunakan sebagian besar untuk urusan pekerjaan selain sebagai sarana berinteraksi dengan teman -teman dan juga keluarga. 
"Kayak kata yg dibalik-balik gitu, kayak cakep tapi gambarnya kecap. Tapi itu lucu sih, saya lebih suka yang kayak gitu-gitulah. Becandaan yang plesetan-plesetan gitu. Jadi kalau nerima yg kayak gitu, lucu sih menurut saya. Dan saya juga kepikiran mau bikin juga sebenarnya... "(Pandu, wawancara 28 Oktober 2020)

Dari hasil wawancara di atas adalah bahwa informan memiliki ketertarikan pada stiker WhatsApp yang seri plesetan, karena minatnya pada gurauan atau candaan yang bersifat "plesetan". Baik itu dalam grup atau personal. Saat infroman mendapat atau melihat stiker versi plesetan maka akan diinterpretasi dan direspon sebagai salah satu arti yang memiliki nrelevansi dengan minatnya akan humor-humor yang bersifat "receh" tadi.

"Di grup SMA saya banyak juga ada beberapa dokter. Dokter-dokter ini ngasih pandangannya terhadap covid-19 sehingga membuat pusing dan jadi ada rasa takut. Akhirnya saya kasih stiker yang sayap ayam dengan tulisan "siyap". Akhirnya jadi membuat cair suasana"(Pandu, wawancara 28 Oktober 2020)

Dalam penuturan informan di atas stiker juga dapat dimaknai atau diinterpertasikan sebagai "ice breaker" ditengah sebuah pembahasan yang terlalu serius atau membosankan bagi sebagaian orang. Dengan diunggahnya stiker "plesetan" tersebut maka percakapan yang tadinya cukup serius menjadi cair. Stiker "siyap" tadi juga dimaknai oleh orang lain yang ada dalam grup tersebut sebagai simbol yang signifikan. Mereka akan merespon atau mengartikan sama terhadap stiker tersebut, sebagai tanda untuk rehat sejenak dari perbincangan yang cukup serius atau yang pada akhirnya hanya dapat diikuti oleh beberapa orang saja. Dalam hal konteks perbincangan tadi terjadi di beberapa teman informan yang memang kebetulan berprofesi sebagai dokter.

Walaupun secara umum memang meme lebih sering sebagai bahan lucu-lucuan dan sarana hiburan di media sosial. Namun meme ternyata dapat mewakili perasaan mereka saat itu. Misalnya pada saat mereka sedang merasa kesal dan di saat yang sama mereka melihat Mereka mengatakan bahwa meme yang mewakili perasaan mereka saat itu biasanya akan dikoleksi. Karena ada perasaan yang dapat diwakilkan dengan meme. Seperti juga diakui oleh mereka, bahwa meme ini sebagai medium ekspresi tentang apa yang sedang dirasakan oleh seseorang.

Meme juga sebagai salah satu "alat" untuk menunjukkan ketidaksukaan atau sindiran jika di sebuah grup WhatsApp terjadi pembahasan yang tidak disukai.

Dalam merespon, meme memang harus ada relevansi dengan si informan, apakah itu lebih ke personal (perasaan saat itu) atau isu yang memang saat itu sedang aktual atau viral. Isu bisa apa saja apakah itu berhubungan dengan isu politik, sosial, atau berita yang sedang viral tentang artis atau selebritas.

Ada juga yang mengoleksi stiker atau meme. Stiker di WhatsApp dipakai sebagai medium untuk saling berbalas saat interaksi di sebuah percakapan di WhatsApp. Kadang juga informan menambahkan caption pada meme tersebut. Meme menurutnya adalah semacam parodi atau "plesetan".

"Suatu hal yang mungkin muncul di keseharian atau hal yang ada, tapi itu dicopot dari konteks asalnya lalu dipakai menjadi ekspresi lain. Banyak yang aku temuin dan menurutku lucu karena ekspresinya. Padahal sumber asalnya belum tentu ngomong hal yang sama." (Pandu, wawancara 28 Oktober 2020) 
Penuturan informan diatas menjelaskan bahwa menurut pengamatannya stikerstiker mengandung kutipan maupun visual yang diambil dari film atau tokoh tertentu bisa artis film, selebritas atau seseorang yang sedang viral. Kemudian konteksnya ada yang memang disesuaikan atau diplesetkan dari konteks sebenarnya, Namun itu dapat dipahami sebagai makna atau arti yang sama dan dihadirkan dengan unsur banyolan.

"Kalau ada yg menarik saya save. Kalau saya butuh saya bisa update atau kasih ke orang, kayak gitu. Ngirim ke orang. Jika ada yang mewakili perasaan saya, saya akan update tuh" (Celine, Wawancara 30 Oktober 2020)

Mereka mengatakan selain sebagai bahan humor tapi stiker tersebut dapat diartikan sebagai ekspresi perasaan mereka pada saat tertentu. Jika menemukan meme yang cocok dengan perasaannya saat itu akan diupdate lalu disave dan jika dibutuhkan bisa dibagikan lagi ke orang lain atau teman. Meme itu selain dikenal sebagai medium ekspresi yang sarat dengan unsur humor juga sebagai ekspresi yang dapat mewakili suasana hati dan akan diupdate ke status WhatsApp. Sehingga meme tersebut akan disave ke telepon genggamnya yang suatu saat bisa dibagikan ke temannya yang lain.

"Saya suka ini pak, suka ngeskip obrolan gitu. Misalnya ada bahasan yang saya gak mau untuk jawab biasanya saya suka kasih stiker tuh. Lebih ke males aja bahas aja, Karena menurut saya gak penting nih. kasih stiker aja nih ... dan biasanya orang itu juga udah tahu langsung gitu kalau saya kasih stiker oh ni orang lagi males nih, orang itu akan diem atau ganti topik..." (Celine, Wawancara 30 Oktober 2020)

Dalam penuturan informan di atas, dalam interaksi yang terjadi dalam percakapan di WhatsApp stiker juga digunakan untuk mengakhiri pembicaraan. Hanya sekedar untuk menyudahi obrolan saja atau karena memang topik obrolannya yang tidak menarik atau malas untuk dibahas lebih lanjut. Biasanya lawan bicara akan mengerti, stiker dimaknai sebagai simbol bahwa yang diajak bicaratidak merespon topik pembicaraan tersebut. Kemudian akan direspon dengan mengakhiri pembahasan atau mengganti topik pembicaraan yang lain.

Meme direspon sebagai salah satu medium untuk berinteraksi dalam suatu percakapan di grup WhatsApp dengan menggunakan format stiker WhastApp atau animasi GIF dan juga gambar meme. Stiker dan animasi GIF tersebut memiliki relevansi dengan topik pembicaraan dan akhirnya dan terjadi apa yang dinamakan significant symbol atau bagaimana sebuah simbol itu dimaknai sama oleh dirinya sendiri dan juga orang lain yang memang ada dalam grup WhatsApp tersebut.

"Stiker nyocokin sama kita lagi ngomongin apa gitu sih. Trus ada stiker yang relate sama obrolan kita trus lucu. Jadi, baru deh tuh kasih stiker... Untuk apa, namanya, melebihlebihkan sesuatu aja sih. intinya supaya lebih lucu aja obrolannya... "(Celine, wawancara 30 Oktober 2020)

Dalam suatu interaksi pembicaraan yang terjadi di grup WhatsApp mereka akan menggunakan stiker yang memang memiliki relevansi atau yang sesuai dengan konteks topik pembicaraan yang sedang terjadi. Mengirim stiker-stiker tersebut dilakukan sebagai bentuk respon agar menambah "keseruan" obrolan yang terjadi saat itu. Sehingga orang lain yang juga ada dan terlibat dalam pembicatraan tersebut pun akan juga merespon dengan stiker lain yang memiliki makna yang sama sebagai penambah "keseruan" obrolan. 
"Meme itu tuh, apa ya... cara lo mengekspresikan diri melalui konteks yang sedang relevan. Sebenarnya meme itu sama seperti postingan media sosial buat gue. Kalau meme itu kita kan ngambil sebuah visual yang relevan ke konteks yang pengen kita highlight kasarnya. Meme itu harus ada konteksnya... yang ingin gue komunikasikan itu apa gue akan mencari visual meme yang tepat untuk mengomunikasikan konteks tersebut. Jadi gue harus tahu mau menulis apa abis itu gue harus tahu visual atau meme yang tepat untuk dikawinkan sama si kata-kata yang akan gue susun itu apa..." (Moksa, wawancara 11 November 2020)

Meme bagi informan di atas dimaknai sebagai sebuah sebuah simbol yang memiliki relevansi dan sesuai konteks pembicaraan atau saat interaksi berlangsung. Sehingga menggunakan meme tersebut si individu harus tahu stiker meme apa yang tepat untuk merespon sebuah pembicaraan atau interaksi yang sedang berlangsung.

"Karena gue ngeliat stiker itu sebagai bentuk respon atas apa yang terjadi, mau berita mau apapun. Kebetulan ada orang yang niat bikinin stikernya, gue sebagai konsumen bisa dapat informasinya dengan cara yang beda aja gitu. Dengan cara yang dibecandain dalam bentuk meme". (Iyus wawancara 28 November 2020)

Ada juga yang merespon stiker sebagai salah satu sumber informasi, yang dikemas dengan unsur humor. Sehingga memotivasi untuk mencari tahu tentang visual yang dipakai dalam meme tersebut sehingga didapatkan informasi baru yang berasal dari visual yang dipakai dalam meme tersebut. Informasi tersbebut bisa seputar lagu, tren, film sampai berita yang sedang viral seperti pemilihan presiden di Amerika Serikat.

Mengenai meme sebagai salah satu sumber informasi alternatif penulis teringat dengan salah satu jurnal berjudul "Penggunaan meme dan teks WhatsApp sebagai bahan mengajar" (Manggong, 2019) yang membahas pemakaian meme untuk media pembelajaran di kuliah yang terbukti cukup efektif. Bagaimana mahasiswa memaknai meme tersebut dengan konteks mata kuliah yang diajarkan.

\section{Interaksi milenial dengan Meme}

Simbol yang terbentuk melalui interaksi terdiri atas simbol verbal dan visual yang terbentuk atas pola-pola tertentu untuk mengekspresikan pemikiran dan perasaan yang dimiliki bersama. Bahasa adalah sistem lambang atau simbol bunyi yang berkembang berdasarkan suatu aturan yang disepakati oleh pemakainya. Setiap lambang bahasa memiliki makna atau konsep.

Dalam hal ini meme sudah menjadi bahasa dalam interaksi milenial di media sosial. Karena seperti juga pengertian bahasa, meme tersebut merupakan simbol-simbol, baik itu berupa stiker Whatsapp maupun Meme Internet menjadi sebuah simbol yang dimaknai bersama oleh pemakainya. Karena pada saat berinteraksi bahasa akan tergantung pada significant symbol yaitu simbol yang pada dasarnya akan menimbulkan makna yang sama terhadap orang lain (West \& Turner, 2010).

Seseorang dapat mempunyai pemahaman atau pemaknaan yang sama dengan orang lain melalui interaksi mereka (Mudjia Rahardjo, 2018), dan makna itu menjadi realitas. Realitas tersebut diakibatkan dari hasil konstruksi melalui pemaknaan. 
Pertukaran simbol tersebut terjadi melalui interaksi dengan simbol visual yaitu gambar berupa foto atau ilustrasi yang digabung dengan teks. Simbol-simbol tersebut akan berpengaruh terhadap interaksi yang dilakukan milenial dalam memahami dan mengintrepetasikan sebuah makna. Apakah itu memiliki konteks terhadap sebuah masalah atau isu yang sedang aktual dan juga yang memiliki relevansi dengan perasaan atau kondisi emosional yang dialami saat itu. Sehingga interaksi yang tercipta antara kedua belah individu diwakili oleh stiker WhatsApp tersebut.

\section{SIMPULAN}

Meme selama ini lebih dikenal sebagai bahan humor atau hiburan saja. Banyak orang yang menganggap meme sebagai seuatu yang identik dengan humor yang bisa bersifat sindiran ataupun hiburan. Namun setelah ditinjau dengan interaksi simbolik ternyata selain unsur humor sebenarnya meme itu bisa dimaknai oleh seseorang, dalam hal ini si milenial, sesuai dengan konteks dan relevansinya dengan apa yang dirasakan. Sehingga setiap orang dapat memaknai meme itu sendiri dari simbol, gambar dan tulisan yang dipakai untuk mengekspresikan apa yang sedang dirasakan. Apakah itu yang bersifat personal maupun keadaan atau sebuah isu yang sedang aktual pada saat itu.

Seperti tahapan yang dikatakan oleh. Blummer yaitu:

1. Manusia akan merespon seseorang atau sesuatu (objek) didasarkan atas pemaknaan yang mereka berikan kepada seseorang atau benda tadi. Benda di sini adalah meme berupa stiker WhatsApp.

2. Makna muncul dari interaksi sosial antara probadi dan individu lain. Dalam hal ini interaksi terjadi didalam media sosial yaitu aplikasi percakapan WhatsApp. Stiker yang dibagikan tersebut akan dimaknai dan direspon oleh Individu-individu yang menerimanya .

3. Interpretasi individu terhadap simbol dimodifikasi oleh proses pemikirannya sendiri. Simbol di sini diwakili oleh meme yang terdiri atas visual dan teks. Individu akan memaknai meme tersebut dengan pemikirannya sendiri selama memiliki konteks dan relevan dengan individu tersebut.

Stiker WhatsApp ini disebarkan melalui aplikasi WhatsApp yang notabene adalah sebuah medium interaksi masyarakat digital saat ini, khususnya para milenial. Saat mereka mendpatakan dan melihat stiker tersebut mereka akan bertindak dalam arti mereka akan memaknai meme tersebut dan menghubungkannya dengan sesuatu yg memiliki relevansi dengan dirinya (konsep mind) dan kemudian akan merespon sesuai dengan konteks interaksi yang sedang berlangsung saat itu. Kemudian pemaknaan terhadap stiker itu muncul tergantung konteks "pembicaraan" dalam interaksi yang terjadi dalam WhatsApp tersebut, apalagi dalam grup WhatsApp yang isinya merupakan "inner circle" atau pertemanan dekat. Pemaknaan yang didapatkan, juga disesuaikan dengan konteks pembicaraan dan siapa yang membagikan meme tersebut. Meme tersebut dapat dimodifikasi kembali sedemikian rupa, disesuaikan dengan konteks pembahasan atau pembicaraan untuk kemudian dibagikan melalui WhatsApp. Jadi terjadi peristiwa di mana stiker sebagai simbol dipertukarkan dalam interaksi di aplikasi chat WhatsApp 
antara milenial. Simbol yang terdiri atas simbol verbal dan visual (foto) melalui penggunaan stiker atau Animasi GIF di aplikasi WhatsApp. Simbol yang dipertukarkan akan memiliki makna tersendiri bagi si pemberi meme maupun yang menerima. Dalam menegosiasikan makna para milenial dalam suatu pembahasan tertentu maupun yang berkaitan dengan perasaan personal, mereka membangun hubungan interpersonal dalam interaksi di aplikasi percakapan WhatsApp dengan saling bertukar simbol. Sehingga kedua belah pihak dapat memahami makna yang diberikan dan baik si pengirim dan penerima memiliki pemahaman makna yang sama.

Hasil penelitian ini memang tidak untuk membuktikan tetapi lebih untuk menggali apa yang mendasari pemaknaan dan respon terhadap meme sebagai bentuk ekspresi yang terjadi dalam merespon interaksi yang terjadi dalam percakapan WhatsApp. Ekspresi tersebut dapat berbeda-beda tergantung dari masing-masing individu dalam memaknai dan merespon meme tersebut. Masing-masing individu akan memilih stiker yang mewakili ekspresi mereka masing-masing.

Penulis juga menemukan bahwa teori interaksi simbolik yang diusung Mead dan Blummer sebenarnya tidak hanya terbatas untuk melihat pemaknaan dan interpretasi terjadi tidak hanya melalui simbol dalam bentuk bahasa, gestur dan ekspresi tapi juga bisa melalui simbol berupa stiker WhatsApp. 


\section{DAFTAR PUSTAKA}

Ahmadi, D. (2016). Interaksi Simbolik. Jurnal Mediator, 9(2), 301-316.

Al-Maroof, R. A., Arpaci, I., Al-Emran, M., Salloum, S. A., \& Shaalan, K. (2021). Examining the Acceptance of WhatsApp Stickers Through Machine Learning Algorithms. Studies in Systems, Decision and Control, 295(July), 209-221. https://doi.org/10.1007/978-3-030-47411-9_12

Dimock, M. (2019). Where Millennials end and Generation $Z$ begins | Pew Research Center. https://www.pewresearch.org/fact-tank/2019/01/17/where-millennials-end-and-generation-z-begins/

Fauzi, R. (2017). Perubahan Budaya Komunikasi pada Pengguna Whatsapp di Era Media Baru. Jurnal Ilmu Komunikasi Efek, 1(1). https://doi.org/10.32534/jike.v1i1.44

Griffin, E. A. (2012). A First Look at Communication (8th ed.). McGraw-Hill.

Indriani, Sri Seti, Prasanti, D. (2019). BUDAYA TUTUR DIGITAL DALAM PERSONAL BRANDING mengapa personal branding dalam brand, namun tidak cukup hanya. 13(1), 133-145.

Jessica, G., \& Franzia, E. (2017). The Analysis of Line Sticker Character "Cony Special Edition." Humaniora, 8(3), 291. https://doi.org/10.21512/humaniora.v8i3.3904

Manggong, L. (2019). The Use of Memes and Whatsapp Message in Teaching Literature. AKSIS: Jurnal Pendidikan Bahasa dan Sastra Indonesia, 3(1), 12-22. https://doi.org/10.21009/aksis.030102

Mudjia Rahardjo. (2018). Interaksionisme Simbolik Dalam Penelitian Kualitatif. Repository.Uin-Malang, March, 1-5. repository.uin-malang.ac.id

Pratnyawan, A. (2019). Gegara Salah Stiker WhatsApp, Remaja Ini Ciptakan Keributan Keluarga. https://www.suara.com/tekno/2019/07/22/155702/gegara-salah-stiker-whatsapp-remaja-iniciptakan-keributan-keluarga?page $=$ all

Putro, F. H. A. (2017). PERILAKU PENGGUNAAN MEDIA SOSIAL DAN IDENTITAS DIRI (Studi Deskriptif Kualitatif Tentang Perilaku Penggunaan Media Sosial dan Identitas Diri di Kalangan Mahasiswa S1 Jurusan Komunikasi Universitas Slamet Riyadi Surakarta). Transformasi, 2(32), 945958.

Revitasari, F. (2015). 31 Macam Orang yang Akan Kamu Jumpai di Grup Chat. https://www.hipwee.com/hiburan/broadcast-dulu-yuk/

Shifman, L. (2014). Memes in Digital Culture. The MIT Press.

Siregar, N. S. S. (2011). Kajian tentang Interaksionisme Simbolik. Prespektif, 4(2), 100-110. http://ojs.uma.ac.id/index.php/perspektif/article/view/86

West, R., \& Turner, L. H. (2010). Richard West, Lynn Turner - Introducing Communication Theory. Analysis and Application. Fourth Edition-McGraw-Hill (2010). 